DOI: $10.6060 / \mathrm{mhc} 170935 \mathrm{k}$

\title{
Template Effect of Pyridinium Salts in the Synthesis of Crown-meso-Tetraphenylporphyrin
}

\author{
Vasily E. Kotsuba, ${ }^{\mathrm{a}, \mathrm{b}}$ Alexandra Ya. Freidzon, ${ }^{\mathrm{c}, \mathrm{d}}{ }$ Nadezhda A. Polyanskaya, ${ }^{\mathrm{a}}$ \\ and Nadezhda M. Kolyadina ${ }^{a}$ \\ ${ }^{a}$ RUDN University, 117198 Moscow, Russia \\ 'FBSI "VGNKI", 123022 Moscow, Russia \\ 'Photochemistry Center, Russian Academy of Sciences, 119421 Moscow, Russia \\ ${ }^{\mathrm{d} N a t i o n a l ~ R e s e a r c h ~ N u c l e a r ~ I n s t i t u t e ~(M o s c o w ~ E n g i n e e r i n g ~ P h y s i c s ~ I n s t i t u t e), ~} 115409$ Moscow, Russia \\ ${ }^{\circledR}$ Corresponding author E-mail: vasilyk@yandex.ru
}

\begin{abstract}
Using pyridine in the presence of pyridinium salts as a reaction medium was suggested for the synthesis of crown-mesotetraphenylporphyrin from pyrrole and podand dialdehyde. We expected that the absence of a free acid in the reaction mixture would minimize the linear polymerization rate of the reactants. Use of the proposed reaction medium has almost doubled the yield as compared to the original published synthetic procedure for the target porphyrin and facilitated purification due to a smaller amount of polymeric impurities. Quantum chemical simulations have demonstrated that the podand precursor could form H-bonded complexes with protonated pyridine and thus become pre-organized for the formation of a porphyrinic macrocycle. The same reaction with benzaldehyde did not produce even trace amounts of the porphyrin. Obviously, this is caused by the higher complexation energy for the podand-pyridinium system compared to benzaldehyde-pyridinium (calculated values are 36 and $24 \mathrm{kcal} / \mathrm{mol}$, respectively).
\end{abstract}

Keywords: Porphyrins, crown ethers, podands, pyridine, template effect.

\section{Темплатный эффект солей пиридиния при синтезе краун-мезо-тетрафенилпорфирина}

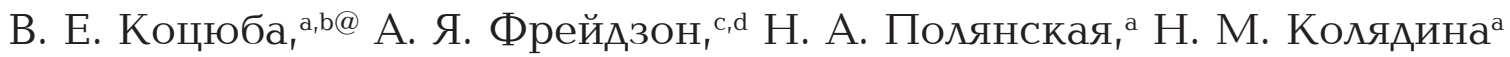

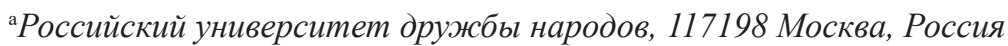

'ФГБУ “ВГНКИ”, 123022 Москва, Россия

'Центр фотохимии РАН, 119421 Москва, Россия

'Национальный исследовательский ядерный институт “МИФИ”, 115409 Москва, Россия

@E-mail: vasilyk@yandex.ru

С ичелью повышения выхода изелевого краун-мезо-тетрафенилпорфирина из пиррола и диальдегида-поданда нами была опробована в качестве реакционной среды следуюшая система: пиридин в качестве растворителя и соли пиридиния (с TFA и HCl) в качестве катализатора. Предполагалось, что отсутствие в реакционной смеси свободной кислоты даст возможность сделать процесс управляемым, а использование пиридина как растворителя, возможно, позволит впоследствии проводить однореакторный синтез соответствующих металлопорфиринов. Оказалось, что в описанной реакционной среде выход иелевого порфирина увеличивается почти вдвое, по сравнению с использованной нами ранее модифицированной методикой Линдси. Кроме того, значительно облегчается очистка продукта, благодаря снижению степени превращения исходных веществ в линейные полимеры. Квантово-химические расчёты показывают, что поданд-предшественник может координироваться с протонированными молекулами пиридина за счёт образования водородной связи. Таким образом, молекула диальдегида становится предорганизованной для образования порфиринового макроцикла, что уменьшает вероятность её линейной сополимеризации с пирролом. Проведение аналогичного эксперимента с бензальдегидом не приводит к образованию целевого порфирина даже в следовых количествах. Скорее всего, это связано с тем, что величина энергии комплексообразования для системь поданд-пиридиний 
значительно больше таковой для системь бензальдегид-пиридиний (расчётные значения 36 и 24 ккал/моль, соответственно).

Ключевые слова: Порфирины, краун-эфиры, поданды, пиридин, темплатный эффект.

\section{Introduction}

Molecules that constitute a tetrapyrrolic core and crown ether subunits present considerable interest as polytopic ligands that can find application in photovoltaics, development of chemical sensors, enzyme modelling and other areas of science and technology. ${ }^{[1]}$ One of the general approaches to synthetic porphyrins, in particular, meso-tetraarylporphyrins, is acid-catalyzed condensation of pyrrole with various aldehyde precursors. ${ }^{[2]}$ The major drawback of this synthetic pathway is the lack of selectivity: the acid present in the reaction mixture induces side processes, namely, the formation of polypyrrole and linear co-polymerization of reactants, often leading to poor product yields and requiring tedious purification procedures. Techniques that use dilute solutions of the reactants produce higher yields ${ }^{[3]}$ but become inconvenient when preparative quantities of target porphyrins are needed. Multi-step synthetic routes exist that involve pyrrole derivatives instead of unsubstituted pyrrole $\mathrm{e}^{[4]}$ but such methods are not well-suited for the synthesis of symmetrical porphyrins $^{[5]}$ and the overall yields can also be not high. Therefore, development of general synthetic procedures that can afford preparative porphyrin quantities from a variety of aldehydes is an actual problem in the chemistry of porphyrins.

Using dialdehyde podand (1) as the starting compound we sought to obtain and study the corresponding bis-crowntetraphenylporphyrin (2). The first attempt to synthesize macroheterocycle (2) by the Adler-Longo procedure was unsuccessful: a black solid was formed, almost insoluble even in such solvents as chloroform, DMSO, and trifluoroacetic acid. The UV-Vis spectrum of a chloroform wash, however, showed the presence of an absorption band at $417 \mathrm{~nm}$, in the Soret region, indicating that the target product formed, although in trace amounts. Using the Lindsey procedure at first proved impractical, giving significant amounts of inseparable impurities, but replacing the usual chloranil/DDQ oxidant with aqueous potassium monopersulfate (Oxone) in the presence of $\mathrm{Et}_{3} \mathrm{~N}$ afforded an $11 \%$ yield of (2). ${ }^{[6]}$ Unfortunately, this modified Lindsey procedure still required tedious chromatographic purification and sometimes produced very stable water-organic emulsions during the work-up thus lowering the product recovery. Therefore, we continued the search for optimal reaction conditions. Obviously, the main issue in using podand (1) as the starting material is its co-polymerization with pyrrole, which needs suppression in favor of controlled formation of the tetrapyrrolic core. The target procedure would allow for a one-pot synthesis of the corresponding porphyrinates.

After much trial and error followed by some consideration, we decided to try pyridine as the reaction medium and pyridinium salts as the catalysts. This decision was based on two aspects. First, even very small amounts of free acids cause undesired polymerization processes to dominate. We assumed that the absence of a free acid could be used to control the pyrrole-dialdehyde condensation process, which is hard or impossible to do otherwise. This could be achieved by using pyridinium salts with strong acids, such as TFA or $\mathrm{HCl}$, known as acidic catalysts $\left.^{[7]}\left(\mathrm{pKa} \mathrm{Dmso}_{\text {DyH }}\left[\mathrm{PyH}^{+} \leftrightarrow \mathrm{Py}+\mathrm{H}^{+}\right]\right)=3.4\right) .{ }^{[8]}$ Second, pyridine is one of the solvents recommended as the medium for the synthesis of metal porphyrinates from pure free tetraphenylporphyrins and metal salts. ${ }^{[9]}$ It should be noted that there is no contemporary data on using pyridine for the synthesis of porphyrinic ligands themselves. Moreover, since Paul Rothemund in the 1930s performed the very first syntheses of tetraphenylporphyrin in methanol-pyridine mixtures and in pure pyridine (sealed vessels, $140-220{ }^{\circ} \mathrm{C}, \sim 3 \%$ yield), it seems that pyridine has been abandoned as a solvent for the synthesis of tetraphenylporphyrins. However, those early syntheses were carried out in the absence of an acidic catalyst and without the knowledge that a significantly strong oxidizer is required to convert the intermediate chlorin to the fully aromatic porphyrin system. Thus, we decided to perform the synthesis of crown-porphyrin (2) in pyridine expecting it to increase the product yield and allow for one-pot subsequent conversion of (2) into the corresponding metal derivatives.

\section{Experimental}

Materials and equipment. Pyridine, pyrrole, trifluoroacetic acid, and basic $\mathrm{Al}_{2} \mathrm{O}_{3}$ were from Alfa Aesar. Benzaldehyde was purchased from Acros Organics. Chloroform, acetic acid, acetonitrile, and $\mathrm{NaHCO}_{3}$ of analytical grade were from Chimmed (Russia). Pyrrole and benzaldehyde were purified directly before use by passing them through short microcolumns with basic $\mathrm{Al}_{2} \mathrm{O}_{3}$. The UV-Vis spectra were recorded on a Cary 50 instrument. LCMS analysis was performed on a Shimadzu LC Prominence chromatograph equipped with a UV-Vis detector and a triple quadrupole mass detector (ESI interface, positive polarity).

Experiment 1. Preparation of crown-porphyrin (2) in pyridine. Dialdehyde (1) (0.83 g, $2.33 \mathrm{mmol})$ and pyrrole $(0.344 \mathrm{~g}, 5.13 \mathrm{mmol}, 10 \%$ excess $)$ were dissolved in $50 \mathrm{~mL}$ of pyridine. The solution was stirred and heated to reflux, then a mixture of $20 \mathrm{~mL}$ pyridine and $5 \mathrm{~mL}$ trifluoroacetic acid was added. The resulting mixture was stirred at $105-110{ }^{\circ} \mathrm{C}$, and UV-Vis spectroscopy was used to monitor the reaction progress as described below. A blank solution was prepared by adding acetonitrile to a $50 \mu \mathrm{L}$ portion of pyridine up to a total volume of $10 \mathrm{~mL}$. The portions $(50 \mu \mathrm{L})$ of the reaction mixture were taken, diluted with acetonitrile to $10 \mathrm{~mL}$, and the spectra were recorded every 10-20 min until the reaction time reached $1.5 \mathrm{~h}$. The mixture was allowed to cool to ambient temperature and was left to stand for $48 \mathrm{~h}$. Extra $30 \mathrm{~min}$ of heating at $\sim 70{ }^{\circ} \mathrm{C}$ did not show considerable increase of the Soret band intensity. Then the mixture was transferred to a separatory funnel, diluted with $300 \mathrm{~mL}$ of water and shaken with $100 \mathrm{~mL}$ of $\mathrm{CHCl}_{3}$. The lower layer was collected and the remaining mixture was extracted with two more $100-\mathrm{mL}$ portions of $\mathrm{CHCl}_{3}$. The combined extracts were subsequently washed with equal amounts of water, $10 \% \mathrm{AcOH}$ (twice), $5 \%$ $\mathrm{NaHCO}_{3}$, and water, then dried over $\mathrm{Na}_{2} \mathrm{SO}_{4}$, and the solvent 
was removed on a rotary evaporator. The residue was redissolved in chloroform $(60 \mathrm{~mL})$, passed through a plug of Celite $(\mathrm{h}=5 \mathrm{~mm}$, $\mathrm{d}=65 \mathrm{~mm}$ ), and evaporated with $20 \mathrm{~g}$ of basic $\mathrm{Al}_{2} \mathrm{O}_{3}$. Column chromatography on basic $\mathrm{Al}_{2} \mathrm{O}_{3}(100 \mathrm{~g}$, column $\mathrm{d}=65 \mathrm{~mm}$, eluting with $0.5 \% \mathrm{MeOH}$ in dichloromethane) afforded $20 \%$ (with respect to dialdehyde) of (2) as a $\sim 1: 1$ mixture of isomers. $\mathrm{m} / \mathrm{z}$ (ESI) (\%): $907(100)\left[(\mathrm{M}+\mathrm{H})^{+}\right]$. The spectral properties of $(2)$ synthesized using the described procedure were identical to those of a sample obtained in a modified Lindsey condensation. ${ }^{[6]}$

Experiment 2. Attempted condensation of benzaldehyde and pyrrole in pyridine. A solution of benzaldehyde $(0.212 \mathrm{~g}$, $2 \mathrm{mmol})$ and pyrrole $(0.201 \mathrm{~g}, 3 \mathrm{mmol}, 50 \%$ excess $)$ in $20 \mathrm{~mL}$ of pyridine was prepared, stirred and heated to reflux. Then a mixture of $4 \mathrm{~mL}$ of pyridine and $1 \mathrm{~mL}$ of trifluoroacetic acid was introduced. The resulting mixture was stirred at $105-110{ }^{\circ} \mathrm{C}$, and UV-Vis spectroscopy was used to monitor the reaction progress as described for Experiment 1. No Soret or $Q$-bands was observed during a 1-h heating. The reaction mixture was allowed to cool down and stirring was maintained at ambient temperature for 48 hours. After that, a UV-Vis spectrum still demonstrated no Soret or $Q$-bands.

\section{Results and Discussion}

The amount of TFA required to start a pyrrole-aldehyde condensation in conventionally used solvents, such as $\mathrm{CHCl}_{3}$, is quite small. So, we started our experiments with a TFA content in the reaction mixture of $\sim 0.2$ vol.\%. A mixture of the reactants in pyridine was prepared and heated to reflux (no reaction signs). Then TFA was carefully added to a portion of pyridine, stirred well and added to the solution of the reactants. We found that $0.2-1$ vol.\% TFA in the reaction mixture caused the reaction rate to be very low, with only a weak manifestation of the Soret band after 1-2 $\mathrm{h}$. The optimal TFA content in our studies was 4-7 vol.\%, causing intensive Soret band absorption in $\sim 30 \mathrm{~min}$. Higher acid content ( $>10$ vol.\%) resulted in increased formation of tarry products. The use of pyridinium hydrochloride showed similar results.

While monitoring the synthesis of crown-porphyrin (2) in pyridine with UV-Vis spectroscopy, we were surprised to find that the formation of a fully aromatic porphyrin core under the studied conditions did not require the addition of an oxidizer, such as DDQ or Oxone. We supposed that conversion of the intermediate products to the fully aromatic macrocycle can be done either by atmospheric oxygen or by the electron-deficient protonated pyridinium species.

By conducting a similar synthesis under air-free conditions we confirmed that the actual oxidant is atmospheric $\mathrm{O}_{2}$. The reaction mixture in this case was maintained in the dark at ambient temperature for a week, when the absence of the Soret band in it was demonstrated by UV-Vis spectroscopy. Stirring the same mixture for about $30 \mathrm{~min}$ in air resulted in the appearance of the Soret band. Figure 1 shows the UV-Vis spectra of the reaction mixture. It should be noted that we could not monitor the reaction mixture for more than $\sim 1.5 \mathrm{~h}$, because the background absorption probably caused by the formation of polypyrrole increased significantly. The spectral data show that at first the corresponding chlorin is formed, with the Soret band at $482 \mathrm{~nm}$ (in $\mathrm{MeCN}$ ), which is then transformed to (2) with the Soret absorption maximum at $414 \mathrm{~nm}$. The dialdehyde absorption band is at $317 \mathrm{~nm}$.

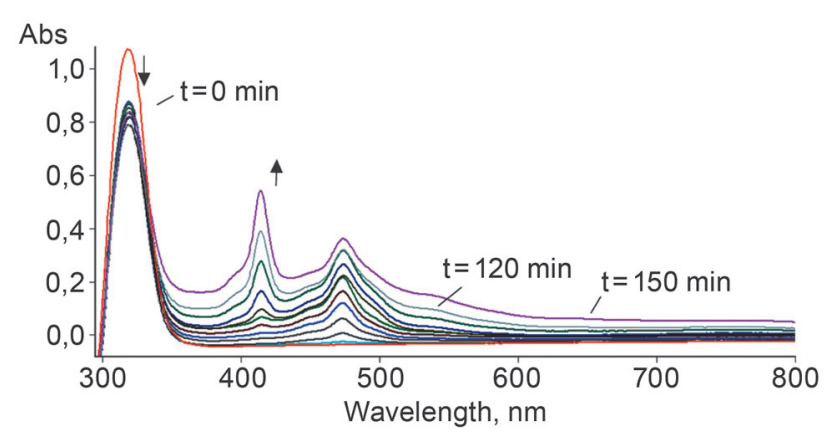

Figure 1. UV-Vis spectra of the reaction mixture.

The aldehyde-pyrrole ratio in the porphyrin synthesis procedures is usually kept at 1:1, or a slight excess of pyrrole is used in order to minimize polymer formation. At first we followed the general literature recommendations and used 10-15\% molar excess (taking into account the presence of 2 carbonyl groups per dialdehyde molecule) of pyrrole. In this case, UV-Vis analysis demonstrated a significant $(\sim 50 \%)$ amount of dialdehyde (1) was left unreacted. Prolonged reaction time did not change the corresponding $318 \mathrm{~nm}$ band intensity; neither did it increase the Soret band intensity. Obviously, sufficient amounts of pyrrole were lost due to self-polymerization or other processes and the formation of porphyrin (2) stopped. However, as dialdehyde (1) remained intact, we performed experiments with a large (five- to tenfold) excess of pyrrole. Under such conditions, total conversion of dialdehyde (1) into crown-porphyrin (2) was achieved in about 3 hours.

The yield obtained in this study is substantially (almost twice) higher than that for the modified Lindsey procedure we published earlier. ${ }^{[6]}$ We suggest this is due to pre-organization of the dialdehyde podand (1) caused by its complexation with pyridinium cations. Quantum chemical simulation (Priroda 14, DFT/PBE, 3z basis) demonstrates that dialdehyde (1) can be pre-organized for the synthesis of crown-porphyrin (2) in two ways. The first one involves the formation of a hydrogen bond of the $\mathrm{Py}-\mathrm{H}^{+}$proton with oxygen atoms of the oxyethylene bridge (Figure 2a). A N-H...O hydrogen bond is formed, with the $\mathrm{H}-\mathrm{O}$ distance of $1.774 \AA$. In the second pre-organization type (Figure $2 b$ ), one hydrogen bond is formed between the carbonyl oxygen and $\mathrm{Py}-\mathrm{H}^{+}(1.553 \AA)$, while the other one, between the other carbonyl oxygen and pyridine ring $\alpha$-hydrogen (1.966 $\AA$ ).

The complexation energy is $33 \mathrm{kcal} / \mathrm{mol}$ in the first case and $36 \mathrm{kcal} / \mathrm{mol}$ in the second. We suppose that protonated pyridinium exhibits a template effect and pre-organizes the molecules of podand (1) from linear or unordered conformations into a form that is optimal for the formation of a porphyrin macrocycle. This was further confirmed by the fact that if protonation is removed, no pre-organization was observed in our simulations. Though we expected podand (1) to form crown ether type complexes with pyridinium cations (type a), the difference in the calculated energy values correspond to about 100:1 prevalence of complexation type (b).

In order to find out whether our synthetic procedure is universal and could be used to obtain a wide range 


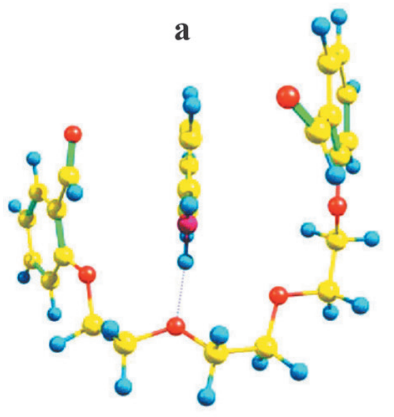

b

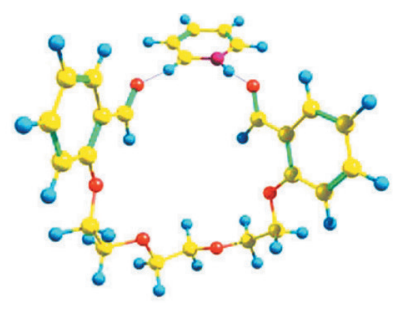

Figure 2. Optimized geometries for the $\mathrm{PyH}^{+}-(2)$ complexes:

(a) first type of pre-organization (complexation energy $33 \mathrm{kcal} / \mathrm{mol}$ ); (b) second type of pre-organization (complexation energy $36 \mathrm{kcal} / \mathrm{mol})$.

of meso-arylporphyrins, we performed an experiment with unsubstituted benzaldehyde. We expected to observe a low to moderate tetraphenylporphyrin yield. However, UV-Vis monitoring of the reaction mixture showed a total absence of a Soret band for $1 \mathrm{~h}$ of the mixture being refluxed and for 2 days of total reaction time. However, these observations once again confirm the template effect of pyridinium salts on the synthesis of crown-tetraphenylporphyrin (2).

The calculated benzaldehyde-pyridinium complexation energy for a 2:1 complex is almost the same as for podand-pyridinium complex type (b). So, we presume that entropy is a major factor in the studied reactions. A [2-benzaldehyde-1-pyridinium] complex dissociates into three particles, a podand-pyridinium complex forms only two. So, in terms of entropy, complexation of podand (1) with pyridinium cations is more favorable compared to benzaldehyde. However, the contribution of entropy to the stability of these complexes is hard to evaluate, because podand (1) can exist in many conformations, moreover, its configurational entropy will be different for free podand molecules and molecules in the complex. If we suggest that 1:1 benzaldehyde-pyridinium complexes are mainly formed, the corresponding complexation energy is $24 \mathrm{kcal} / \mathrm{mol}$, which is sufficiently lower than that of podand-pyridinium complex. These data can explain the formation of crownporphyrin (2) and the absence of tetraphenylporphyrin under the studied conditions.

As a preliminary result we hereby report a successful conversion of crown-porphyrin (2) into its zinc derivative which was achieved by further heating the reaction mixture in pyridine in the presence of zinc acetate. The reaction is somewhat slow but accelerates when water is introduced. The corresponding absorption bands (in a $\mathrm{Py}-\mathrm{H}_{2} \mathrm{O}-\mathrm{MeCN}$ mixture) are observed at $425 \mathrm{~nm}$ (Soret), 558 and $598 \mathrm{~nm}$ (Q-bands).

\section{Conclusions}

We demonstrated the possibility of using pyridine as a solvent and pyridinium salts as catalysts for the synthesis of a crown-tetraphenylporphyrin from pyrrole and a dialdehyde podand, which are very susceptible to self-polymerization and co-polymerization side processes. A template effect was observed for the used pyridinium salts, namely trifluoroacetate and hydrochloride. A similar experiment using benzaldehyde did not lead to the formation of tetraphenylporphyrin even in trace amounts. Quantum chemical calculations were used to evaluate complexation energies. The results demonstrate that complexation of protonated pyridine with dialdehyde podand is significantly favorable in terms of energy and can occur either at dialdehyde's oxyethylene chain or at its carbonyl groups. Both coordination types lead to manifestation of $\mathrm{PyH}^{+}$template effect. Preliminary data demonstrates that metal derivatives of crown-porphyrin (2) can be obtained in pyridine using one-pot procedures.

Acknowledgements. The publication was prepared with the support of the "RUDN University Program 5-100". Equipment of the Shared Research and Educational Center of Physico-Chemical Studies of New Materials, Substances and Catalytic Systems of RUDN University was used in this study.

\section{References}

1. Engelkamp H., Nolte R.J.M. J. Porphyrins Phthalocyanines 2000, 4, 454-459.

2. Adler A.D., Longo F.R., Shergalis W. J. Am. Chem. Soc. 1964, 86, 3145-3149.

3. Lindsey J.S., Schreiman I.C., Hsu H.C., Kearney P.C., Marguerettaz A.J. J. Org. Chem. 1987, 52, 827-836.

4. Rao P.D., Dhanalekshmi S., Littler B.J., Lindsey J.S. J. Org. Chem. 2000, 65, 7323-7344.

5. The Porphyrins. Vol. 1 Structure and Synthesis (Dolphin D., Ed.), New York: Academic press, 1978.

6. Kotsuba V.E., Kolyadina N.M., Soldatenkov A.T., Khrustalev V.N. Macroheterocycles 2013, 6, 74-76.

7. Wang W., Liu H., Xu Sh., Gao Y. Synth. Commun. 2013, 43, 2906-2912.

8. Bordwell F.G. Acc. Chem. Res. 1988, 21, 456-463.

9. Lebedeva N.Sh., Mikhailovskii K.V., V'yugin A.I. Russ. J. Coord. Chem. 2001, 27, 751-755. 